\title{
Max Wertheimer (2020): Productive Thinking. New edition by Viktor Sarris. Birkhäuser/Springer Nature, ix + 257 pages, 485s/ w-Abbildungen; Paperback/Euro 35, 30 - ISBN 978-3-030-36065-8, eBook/Euro 26,75 - ISBN 978-3-030-36063-4.
}

Seventy-five years after its first release, a new edition of a remarkable book has been published by Springer Nature in 2020 in both its English and German versions. It is the only book that Max Wertheimer, the main founder of Gestalt theory, has left us. That it appeared at all in 1945 was almost a miracle for two reasons: First, Wertheimer has inspired numerous other people to important publications and accompanied them in the process (sometimes dictating parts of their publications to them) - but he himself published only a few treatises (albeit very significant ones) under his name (for a complete bibliography, see Wertheimer 2012, edited by Lothar Spillmann, p. 271-274). In the case of this one book "Productive Thinking" it was for once the other way round: Without the persistent urging and active assistance of others, above all his colleague Solomon E. Asch, he would probably never have finished this book and given it out of hand - not even under the reservation that it should only be the first of a series of three books, as "a kind of prolegomena." Even then, the actual appearance of the book was at first very much in doubt. The manuscript was rejected by one renowned publisher after another-in an appreciative tone but firmly—because of insufficient sales prospects $^{1}$. Max Wertheimer was thus not to live to see it finally accepted and published by Harper, New York, in 1945, in the second year after his death.

Since its first publication in 1945, the book has gone through numerous further editions in English, beginning in 1959 in an expanded version edited by Michael Wertheimer ${ }^{2}$, followed by several reprints until 1982. It has been translated into six further languages: Wolfgang Metzger provided the German translation, published by Waldemar Kramer (Frankfurt am Main) in 1957, with the second edition in 1964. Unfortunately, it says a lot about the development of psychology in the German-speaking world that this work by one of its most important representatives was not available in German for half a century after this second edition.

\footnotetext{
1 On the difficult birth of "Productive Thinking" see "The Dynamics and Logic of Productive Thinking: The Crystallization of a Life Study," King \& Wertheimer 2005, 341-365.

2 The enlarged edition 1959, followed by several reprints, included, in addition to the chapters in the original edition of 1945, three further chapters that had been envisioned by MW in an earlier table of contents and for which drafts were available: "The Bridge Problem"; "Plus Three, Minus Three"; and "The Square of a Binomial, Learning Arithmetic."
}

O Open Access. $\odot 2021$ Stemberger, published by Sciendo. (c) BY-NC-ND This work is licensed under the Creative Commons Attribution NonCommercial-NoDerivatives 4.0 License. 
Even before the German version, Wertheimer's "Productive Thinking" appeared in 1952 in a Japanese translation (Tatsuro Yatabe) from the Iwanami publishing house in Tokyo. This was followed by editions in Russian and Chinese (both 1987), in Spanish (1991), and—with Paolo Bozzi as editor-in Italian in 1997 and 2019. The new English-language edition now available from Springer Nature was edited by Viktor Sarris, holder of the Max Wertheimer Chair at the University of Frankfurt until his retirement. It is a reprint of the original 1945 edition, supplemented by a "Preface to the New Edition" and a thorough "Introduction to Max Wertheimer: Productive Thinking" - both authored by Viktor Sarris.

As Max Wertheimer himself stated in his preface to the 1945 first edition, he saw this book as only part of a much more comprehensive endeavor. "It is a kind of prolegomena. I hope I shall be able to finish two other books to which this is a mere introduction." (33) What he had in mind can be inferred from a note he left behind, quoted in Michael Wertheimer's Editor note of the Enlarged Edition: "Two books must follow: one on the broader aspects of the psychology of thinking, the other on the problem of gestalt logic in which the traditional issues appear as the Euclidian special case. Here also the features of productive gestalt heuristics will have to be treated" (Wertheimer, 1959, p. xx).

This first book, Productive Thinking, which was never followed by its two planned continuations, addresses a question that is as simple as it is challenging. Max Wertheimer puts it this way: "What occurs when, now and then, thinking really works productively? What happens when, now and then, thinking forges ahead?" - "What really takes place in such processes? What happens if one really thinks, and thinks productively? What may be the decisive features and the steps? How do they come about? Whence the flash, the spark? What are the conditions, the attitudes, favorable to such remarkable events? What is the real difference between good and bad thinking? And in connection with all these questions: how improve thinking? your thinking? thinking itself?" (37)

Wertheimer pursues these questions in his characteristic way. He starts with the statement "There are fine cases" (for productive thinking, in contrast to a purely reproducing thinking). He selects some such cases and examines them in the conviction to be able to gain insights into the lawfulness operating in them. This approach to the subject in this book is in line with Max Wertheimer's approach in his seminars on Productive Thinking and Problem Solving between 1936 and 1941 at the New School of Social Research, documented by Abraham S. Luchins and Edith H. Luchins: "We will concentrate on concrete cases of problem solving in order to see what happens in such situations." (Luchins \& Luchins, 1970/I, p. 2) To approach the topic of productive thinking in a problem-centered rather than a theory-centered way seemed advisable to Wertheimer if only because "we need more observation and experimentation on productive thinking, more 
information about the nature of creative activities and about the processes involved in them. Moreover, even if there were a universally accepted theory of thinking, it might still not be advisable to start with it because the theory might blind us to certain nuances of creative thinking" (ibid, $3 \mathrm{f}$ ).

The selected cases are presented in seven chapters: The area of the parallelogram The problem of the vertical angles - The famous story of young Gauss - Two boys play badminton; a girl describes her office - Finding the sum of the angles of a polygon - A discovery by Galileo -Einstein: the thinking that led to the theory of relativity (this last chapter alone, which emerged from a large number of Wertheimer's personal conversations with Einstein, beginning as early as 1916 and continuing over many years, would make reading this book a unique experience). Three chapters deal with problem-solving situations in which children and adults are confronted with simple mathematical tasks, supplemented by observations from the classroom, but also by self-observation of MAX Wertheimer (MW) in solving selected problems. One chapter placed in the center of the book deals with the emergence and constructive solution of interpersonal problems. Three chapters analyze the thinking of three well-known personalities of intellectual history on the basis of concrete problems they had to solve: Galileo Galilei, Carl Friedrich Gauss, and Albert Einstein. These "case studies" are followed by a Conclusions chapter: "Dynamics and Logic of Productive Thinking".

Throughout the book, on the basis of the selected cases of problems and problem solutions, there is a critical discussion of the psychological theories of thinking most popular at the time (and probably still today), which are based either on a variant of the "logical method" or on one of the "associative method." It is shown that the productive processes of thinking and problem solving studied in the cases of this book could not be conclusively explained either as cases of by following some particular rules of formal logic or as cases of associatively borrowing solutions from other cases. Rather, other processes and dynamics were to be observed in the cases studied, suggesting regularities that point beyond these individual cases and can be incorporated into a Gestalt theory of productive thinking.

Typical for the book is thus the centering on the concrete individual case as a starting point for the exploration of general regularities in problem-solving thinking, which until then had been hidden by the blindfold of a fixation on formal logic and association. This approach, typical for MW, may be one reason why his book did not become the darling of the so-called cognitive revolution, which-as far as it resorted to Gestalt psychology—preferred to turn to Duncker 1945 than to Wertheimer 1945 for the development of its concepts of cognition as information processing (without really understanding the connection between Duncker and Wertheimer). 
But other reasons could also have been responsible for this. For Wertheimer, thinking was never isolated from the entire human life process, and this remains palpable throughout his book. "Generally speaking, it is an artificial and narrow view which conceives of thinking as only an intellectual operation, and separates it entirely from questions of human attitude, feeling, and emotion just because such topics belong to other chapters of psychology." So it is not surprising that the book is permeated with reflections on the importance of good, creative thinking for a peaceful, just, and constructive coexistence of people, for the solution of social problems, and for democracy. This does not leave out the question of what obstacles there may be to people thinking productively and solving the problems they face in a creative and constructive way.

It was not only owing to MW's personal nature and preference that the focus of his book and the examples chosen for it were on the positive, successful case. Turning first to the successful case and not to the failing one is, as is well known, also methodologically advisable. At the same time, however, it is always clearly stated throughout the whole book that there are also forces and circumstances that can prevent this positive, successful case. On this subject, the book mentions, for example, the harmful effect of drill in education and in the school system, but also the blinding effect of an inappropriately egocentric attitude. The fact that such obstructive forces and circumstances also need to be investigated is not only repeatedly addressed in this book - it is also expressed in a number of significant research projects that MW has stimulated among his students and collaborators for over two decades. Some of them are also mentioned in the book, such as the study of psychiatrist Heinrich Schulte, co-authored by MW (without mentioning MW as a co-author), in the early 1920s, on the origin and cure of paranoid delusions (Schulte, 1924/1986); a study of his assistant, psychiatrist Erwin Levy, on disturbances of thought in people diagnosed as "schizophrenics" (Levy, 1943); and studies on mechanization in problem solving and thinking (Asch, 1940; Luchins, 1942) - some were published after this book had appeared in 1945, like Luchins \& Luchins, 1959 and others.

In 1940 Max Wertheimer published a treatise on human freedom entitled "A Story of Three Days," which can also be read as a treatise on productive thinking (cf. Henle, 1980). There you will find the following summarizing statements towards the end of this essay:

"Freedom is (1) a condition in the social field, and a terribly important one. In viewing such a condition we should not view it as a thing in itself and so define it, but we should view it in its role, in its function, in its interactions, in its consequences for men and for society. Freedom is logically (2) not just a condition; what matters is how men are and how they develop, how society is and how it develops. Freedom is a Gestalt quality 
of attitude, of behavior, of a man's thinking, of his actions. ... Now logically freedom as condition (1) and freedom as Gestalt quality (2) must be viewed not as two pieces, but in their intimate interrelation." (Wertheimer, 1940 in 1961, p. 64).

What Wertheimer says here about human freedom probably also applies to how he sees productive thinking, namely as determined on the one hand by the conditions in the social field that can promote or hinder free thinking, and on the other hand as a Gestalt quality of the person's attitude toward the challenges and opportunities of life. Making these ideas accessible again through the new edition of this book, for which Viktor Sarris deserves thanks and appreciation, should be a contribution to the enrichment of our science of thinking and problem solving today, but above all an encouragement to every reader to take the risk and the pleasures of productive thinking in every day life.

\section{Gerhard Stemberger, Vienna and Berlin}

\section{References}

Asch, S. E. (1940). Some effects of speed on the development of a mechanical attitude in problem solving. Paper read at the 1940 meeting of the Eastern Psychological Association.

Duncker, K. (1945). On Problem-Solving. Psychological Monographs, Vol. 58, No. 5. Washington DC: A.P.A. English translation by Lynne S. Lees of the original publication in German 1935: Zur Psychologie des produktiven Denkens, Berlin: Springer.

Henle, M. (1980). A tribute to max Wertheimer: Three stories of three days. Psychological Research, 42, $295-304$.

King, D. B., \& Wertheimer, M. (2005). Max Wertheimer \& Gestalt Theory. New Brunswick, USA/London, UK: Transaction.

Levy, E. (1943). Some aspects of the schizophrenic formal disturbance of thought. Psychiatry, 6, 55-69.

Luchins. A. S. (1942). Mechanization in problem solving: The effect of Einstellung. Psychological Monographs, Vol. 54, No. 6. Washington DC: A.P.A.

Luchins, A. S., \& Luchins, E. (1959). Rigidity of Behavior. A Variational Approach to the Effect of Einstellung. Eugene, OR: University of Oregon Books.

Luchins, A. S., \& Luchins, E. (1970/I-III). Wertheimer's Seminars Revisited. Problem Solving and Thinking. Vol. I-III. Albany, New York: Faculty-Student Association, State University of New York at Albany.

Schulte, H. (1924/1986). Versuch einer Theorie der paranoischen Eigenbeziehung und Wahnbildung. 1924 in Psychologische Forschung, 5, 1-23. Full English translation by Erwin Levy 1986: A Gestalt Theory of Paranoia. Introduction, Comment and Translation of ,Heinrich Schulte'. Gestalt Theory, 8, 230-255.

Wertheimer, M. (1940/1961). A story of three days. In R. N. Anshen (Ed.), Freedom: Its Meaning. New York: Harcourt Brace, Reprinted in M. Henle (ed., 1961), Documents of Gestalt psychology. Berkeley and Los Angeles: University of California Press, 52-64.

Wertheimer, M. (1959). Productive Thinking. Enlarged Edition. Edited by Michael Wertheimer. With a new Preface by Anders Ericsson, Peter G. Polson, and Michael Wertheimer. New York: Harper.

Wertheimer, M. (2012). On Perceived Motion and Figural Organization. Edited by Lothar Spillmann. Cambridge, MA/London, UK: The MIT Press. 